Other reviews cover the scientific aspects of ageing, the control of protein synthesis in living cells, and pulmonary hypersensitivity caused by organic dusts. Two main types of allergic reaction have been distinguished, called Type I and Type III, and they may be present in lung disease either separately or together. Type I allergy is induced by exposure to everyday dust, and as many as 10 per cent of the population are at risk, but it leaves no tissue damage. Type III is induced by constant exposure to dusts, and the reaction, which involves tissue damage, develops more slowly. Farmers inhaling the dust from damp and mouldy hay, pigeon fanciers and granary and sugarcane workers are all found to suffer from this disease. Tests now malke it possible to diagnose these different diseases, and farmer's lung is already registered as an industrial disease.

\section{Science in Belgium}

The Belgian National Council for Scientific Policy has just published its report for 1967. It fears that the fact that Belgium lags behind other European states in science and technology may be prejudicial to her economic integration into Europe. Belgium cannot reasonably expect to compare in scientific output with the greater European countries; this would require a disproportionate percentage of the gross national product to be spent on research. It is the aim of the council to bring Belgium up to the level of the smaller European countries, such as Sweden or Holland. To this end, the council recommends that by 1972 expenditure on science should have risen to $2 \cdot 15$ per cent of the GNP. Government spending must rise from 8.2 million franes in 1966 to $17 \cdot 8$ million in 1972 , when it is expected to comprise 3.42 per cent of the budget.

The council has appointed commissions to prepare the budgets for research establishments and deal with the expansion of the university system, and to study the means by which research programmes are directed and financed. A good deal of administrative reorganization will be necessary, especially that concerned with technological as opposed to basic research. A greater knowledge of the research facilities and trends in Belgian industry is needed, and the council has already begun collecting this kind of information.

An interesting proposal is that the council should recommend the salaries of research workers attached to projects subsidized by the State.

\section{New Man for Universities}

THE fuss about university accountability has already revealed one unexpected fact. The Committee of Vice-Chancellors and Principals, a conspicuously modest and self-effacing body which represents universities at times like these-and tends to disappear in the interim-has a new chairman. He is $\mathrm{Dr}$ D. G. Christopherson, Vice-Chancellor and Warden of the University of Durham. He took over as chairman early in July, and although nominally elected for one year, it will be breaking all the traditions of a particularly traditional organization if he is not re-elected on the nod for a further two terms. This was what happened to his predecessor, Sir Charles Wilson.
Dr Christopherson has experience in a number of posts, and, perhaps fortunately in his new job, of a great variety of universities. After graduating at University College, Oxford, he was Henry Fellow at Harvard University in 1938, and a scientific officer in the Ministry of Home Security during the war. Since the war he has been a demonstrator and lecturer at Cambridge, professor of mechanical engineering at Leeds and of applied science at Imperial College, before going to the University of Durham in 1960. In 1961 he was chairman of the academic planning board for the University of Kent, and has been a member of the Science Research Council since 1965. In the present atmosphere of uncertainty, universities may be glad that there is a new man at the helm, although $\mathrm{Dr}$ Christopherson might well have preferred to have been pitched in at a less controversial moment.

\section{Golden Gates}

CoNSIDERING California's wealth in laboratories and scientific institutes, it is not surprising to learn that she receives the lion's share of American federal funds for research and development. In fact, California received 31.7 per cent of the $\$ 14,400$ million spent in 1965 ; the second largest share went to New York with nearly 9 per cent; Maryland received $6 \cdot 1$ per cent; Massachusetts and Texas each received 5.1 per cent. These figures come from the National Science Foundation's report on the "Geographical Distribution of Federal Funds for Research and Development".

Between 1963 and 1965, Federal spending on research and development rose by 17 per cent, from $\$ 12,250$ million to $\$ 14,400$ million. In this period, fourteen States showed a decrease in spending and thirty-seven an increase in spending. The change in distribution was largely caused by the phasing out of the Gemini programme and the building up of the Apollo programme, and the completion by the Air Force of several large weapon systems.

On a prime contract basis, 63 per cent of the Federal research and development spending went to industry, 21 per cent to Government laboratories, 8 per cent to educational institutions, 4 per cent to federal contract research centres administered by educational institutions, and 4 per cent to other non-profit-making institutions. As might be expected, a large proportion of the Government laboratories are in or around Washington, and so three States-Maryland, the District of Columbia, and Virginia-received almost a third of the spending on Government laboratories. California received a sixth of the spending in this sector.

The universities have had a greater increase in their share of federal research and development spending than either industry or the Government laboratories; in 1963 they received $\$ 851$ million and in 1965 they received $\$ 1,200$ million. Although the universities receive only 8 per cent of the total federal research and development spending, their influence is far more extensive because they train scientific manpower and provide consulting services and technical expertise to both industry and Government. New York, California and Massachusetts received 37 per cent of this educational institution spending, thanks to the influence of seven universities: Columbia and Cornell in New York, California (Los Angeles and Berkeley) and Stanford in California; and MIT and Harvard in Massachusetts. 